$$
\begin{aligned}
& \text { 湿式ジェットミルを用いたセルロースナノファイバー表面への } \\
& \text { 銀ナノ粒子の固定化 } \\
& \text { 古谷 充章* 藤井 英司 }{ }^{*} \text { 小倉 孝太** }
\end{aligned}
$$

\title{
Immobilization of Silver Nanoparticles on the Surface of Cellulose Nanofibers Using High-Pressure Wet-Type Jet Mill
}

by

\author{
Mitsuaki FURUTANI*, Eiji FUJII* and Kota OGURA**
}

\begin{abstract}
Composite material immobilized silver nanoparticles (NPs) on the surface of cellulose nanofibers (CNF) was prepared using a high-pressure wet-type jet mill. A mixture containing both aqueous silver nitrate solution and CNF suspension were prepared as raw starting materials. The mixture was pulverized with a high-pressure wettype jet mill at a pressure of $100 \mathrm{MPa}$ or $200 \mathrm{MPa}$. An X-ray diffraction pattern of the obtained sample revealed not only cellulose type I crystallites, but also silver metal crystallites. According to observation by field-emission scanning electron microscopy, it was found that many silver NPs were immobilized on the surface of CNF. Note that almost the silver NPs were well dispersed on the surface of CNF. It was cleared that the silver NPs had spherical in shape with an average particle size of about $3 \mathrm{~nm}$ by the transmission electron microscope observation. The average size of silver NPs was slightly increased with increasing the number of jet milling, however, the change in discharge pressure of the high-pressure wet-type jet milling did not affect the size of silver NPs. The silver content in the composite materials increased with increasing both the number of jet milling and the discharge pressure. The silver particles were deposited with using the thermal energy caused by the jet milling, and then their grain growth was inhibited since the suspension was cooled immediately through the cooling tube. Therefore, it was assumed that silver NPs with a narrow size distribution could be immobilized on the surface of CNF.
\end{abstract}

\section{Key words:}

Silver nanoparticles, Cellulose nanofiber, Composite material, High-pressure wet-type jet mill, Immobilization,

Microchemical process

\section{1 緒 言}

金属粒子をナノサイズにまで微細化した粒子は, 金属ナノ粒子 と呼ばれ,それらはバルク状態の金属と比較して高比表面積と高 い表面活性を有することを特長とする. そのため, 金属ナノ粒子 は, バルク状態に比べ, 少量でも大幅に向上させた性能を発現す ることが期待できる. 金属材料の中でも特に, 銀は貴金属であり ながら, 比較的安価な材料であり, 優れた物理的・化学的特性を 有しているため, 様々な用途で利用されている. 更に, ナノサイ ズ化することにより, 電子特性や光学特性, 触某特性, 抗菌性な どの特性が向上するため, 近年では, エレクトロニクス分野や抗 菌材料としての需要が高く, 高機能性材料として着目されている 1) 6).

銀ナノ粒子の合成方法は, 大きく分別してブレイクダウン法 (粉砕法) とビルドアップ法 (合成法) があり, ナノサイズの粒
子を作製する際は, ビルドアップ法が主である. 中でも, 液相中 での銀ナノ粒子の合成手法は, 比較的容易なため, 多くの研究が 報告されている. 水素化ホウ素ナトリウムやエチレングリコール のような強い還元力を有する薬剤を用いて, 金属塩を還元させる 化学的手法7) やレーザーアブレーション法8), エマルション法9) などが報告されている. また，これらの手法では粒成長の抑制や 凝集防止の目的で, ポリビニルピロリドン (PVP) やドデシル硫 酸ナトリウム (SDS) のような保護材を用いることが多い ${ }^{10)}$. 高 機能な銀ナノ粒子を利用するには, 銀ナノ粒子の化学的安定性が 重要になる. 一般的に, 高比表面積と高い表面活性を有している 金属ナノ粒子は, 化学的安定性が低いため, 粒子同士の凝集や表 面の化学状態の変化により, 容易にナノ粒子の特性を失う. その ため，銀ナノ粒子表面をPVP のような高分子保護材で被覆する 手法を施す。その際, 銀ナノ粒子表面を保護材が覆ってしまうこ

$\dagger$ 原稿受理 令和2年6月16日 Received June 16,2020 C2021 The Society of Materials Science, Japan

* 岡山県工業技術センター ○701-1296 岡山市北区芳賀 Indust. Tech. Center of Okayama Pref., Haga, Kita-ku, Okayama, 701-1296.

** (株)スギアシン テ937-8511 䰹市本江 Sugino Machine Limited, Hongo, Uozu, 937-8511 
とにより, 表面活性が阻害され, 特性が低下寸る可能性がある. そこで, 筆者らは, 銀ナノ粒子を基材に固定化する手法に関する 検討を行った. 基材の表面上に金属ナノ粒子を固定化する手法は, 金属ナノ粒子表面を露出させているため, 高い表面活性を維持し たまま金属ナノ粒子を安定化できることが期待できる.

筆者らは, 銀ナノ粒子の固定基材として, セルロースナノファ イバー (CNF) に着目した. CNF は, セルロースをナノサイズに まで微細化したファイバー状の材料であり, 高弾性率や低線熱膨

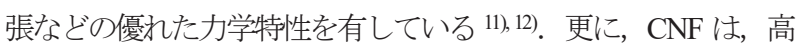
い化学的安定性も有しているため, 銀ナノ粒子の固定基材として の利用を期待できる. ナノサイズの銀粒子を固定化するには, ナ ノサイズのファイバーが適していると考え, 両者を固定すること による複合化を検討し,ナノサイズ同士の粒子とファイバーの特 長を融合させた機能性材料の開発を行った.

銀ナノ粒子と CNF は共に, 高い自己凝集力を有しているため, これらの複合化は, スターラー撹拌等のような簡便な混合操作で は不均一な状態になることが予想される. CNF 懸濁液は $1 \mathrm{wt} \%$ の固形分濃度でも粘度が高く, 更に, 金属ナノ粒子の凝集力が非 常に強いことより,均一分散を困難にする要因になると考えられ る. 現在までに, Fujii らは, CNF と湿式ジェットミルを利用し た銀ナノ粒子の作製について報告している ${ }^{13)}$.この手法は, 金属 塩水溶液と CNF の混合懸濁液を湿式ジェットミルで処理する手 法であり, CNF 自体の酸化処理や水素化ホウ素ナトリウム等の 還元剤を不要とし，バルクのセルロースには無いCNF の僅かな 還元能を有効に利用する方法である. 作製した銀ナノ粒子は, CNF の表面上に析出し, 固定化されているため, 銀ナノ粒子／ $\mathrm{CNF}$ 複合体を形成している，また，合成はワンステップで完了 するため, 非常に簡便である. 金属ナノ粒子は, 形状やサイズに より，その特性が大きく変化することが報告されている 14) 16. したがって, 金属ナノ粒子材料は, 粒子サイズや形状, 濃度等を 精密に制御することが要求される. これまでの報告では, 湿式ジ エットミルの処理条件が, 固定化される銀ナノ粒子の粒子サイズ や担持量に及ぼす影響についての詳細な検討は行われていない.

本報では，硝酸銀水溶液と $\mathrm{CNF}$ の賏濁液を湿式ジェットミル で処理する際の吐出圧と処理回数を変えて試料を調製し, 処理条 件が CNF 上に固定化される銀ナノ粒子に与える影響について検 討を行った. また, 湿式ジェットミル処理により生じる熱エネル ギーが, 銀粒子の析出および固定化に及ぼす影響について検討を 行った.

\section{2 実 験 方 法}

原料の CNF 䀣濁液は，BiNFi-s 極短（(株）スギノマシン製） を用い，固形分濃度 $0.8 \mathrm{wt} \%$ の CNF 縣濁液を $100 \mathrm{ml}$ 調製した. 調製した CNF 懸濁液はスターラーで撹拌した後, 湿式ジェット ミル (HJP-25001，（株）スギノマシン製）を用いて，吐出圧 100 $\mathrm{MPa}$ で 1 回, 処理を行った. CNF 䀣濁液に $74 \mathrm{mM}$ の硝酸銀水溶 液（富士フイルム和光純薬工業（株）製）を $100 \mathrm{ml}$ 加え，60 分 間スターラーを用いて擋拌した. 混合懸濁液は湿式ジェットミル を用いて，吐出圧 $100 \mathrm{MPa}$ および $200 \mathrm{MPa}$ の条件で $0 \sim 20$ 回処
理を行った. 処理後の懸濁液は, 直ちに $10^{\circ} \mathrm{C}$ に保持された冷却 管内を通り, 冷却された. 処理した混合懸濁液は, 遠心分離 $(6,800$ $\times g, 5$ 分間) により固液分離をし, ペースト状の固形分を回収 した. 回収したペースト状試料に超純水を $50 \mathrm{ml}$ 添加し, スター ラーで 10 分間混合した後, 遠心分離により固液分離を行い, 固 形分を回収した. この洗浄工程を 3 回繰り返し, 未反応の硝酸銀 水溶液を取り除いた. 以降, 吐出圧 XMPa で $\mathrm{Y}$ 回処理して作製 した試料名をX-Y と略す。

回収した試料は透過型電子顕微鏡 (TEM; JEM-2100, 日本電子 (株) 製)による観察を行った. 適度に希釈したペースト状試料 を支持膜付き $\mathrm{Cu}$ メッシュ（ウルトラハイレゾカーボン UHR$\mathrm{C} 10$, 応研商事 (株) 製) 上に一滴, 垂らし, 自然乾燥させ, 観 察用試料とした. TEM 観察写真中の 100 個の粒子サイズを測長 し，平均粒子サイズを算出した。

試料中の銀含有量は, ICP 発光分光分析 (ICP; iCAP6500Duo, サーモフィッシャーサイエンティフィック (株) 製) により 3 回 測定し算出した. ペースト状試料に $(1+1)$ 硝酸を $10 \mathrm{ml}$ 加え 250 ${ }^{\circ} \mathrm{C}$ のサンドバス上で 30 分加熱し，ろ過による固液分離を行い， ろ液を測定用試料とした. また, 回収したペースト状試料は凍結 乾燥を行い, カッターミルにより粉砕し, 粉末試料を得た. 粉末 試料は粉末 X 線回折測定 (XRD; SmartLab，(株) リガク製）に よる結晶相の同定を行い, 電界放出形走査型電子顕微鏡（FESEM;SU8220，(株) 日立ハイテク製)により形態観察を行った.

比較試料として, 同濃度の硝酸銀水溶液を調製し, 湿式ジェッ トミルを用い，吐出圧 $200 \mathrm{MPa}$ で，20回処理を行った試料を用 意した. 湿式ジェットミル処理有無の試料の吸光度測定 (UV-vis; UV-3100PC，（株）島津製作所製）を行った.

\section{3 実 験 結 果}

Fig. 1 に, 硝酸銀水溶液を湿式ジェットミルで吐出圧 $200 \mathrm{MPa}$ で，20 回処理した溶液と末処理の硝酸銀水溶液のUV-vis スペク トルを示す. $300 \mathrm{~cm}^{-1}$ 付近のピークは硝酸イオンに起因するピー クである ${ }^{17), 18)}$. 銀ナノ粒子は, $400 \mathrm{~cm}^{-1}$ 付近にプラズモン共鳴に 起因する吸収ピークを持ち, 銀ナノ粒子の粒子径が大きくなるほ

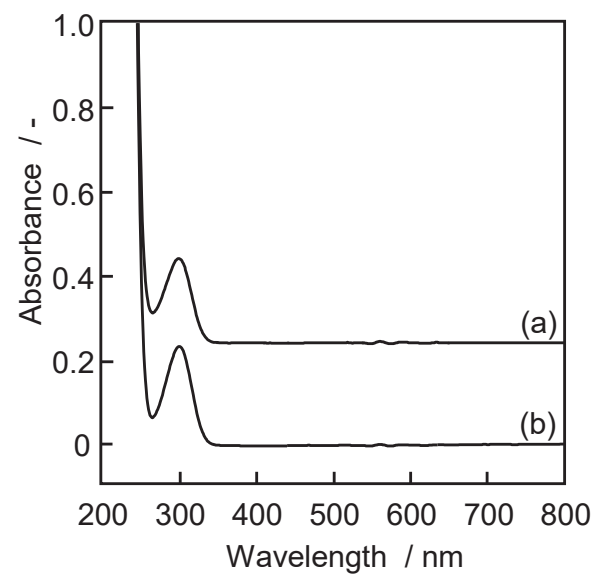

Fig. 1 UV-vis spectra for the sample prepared by pulverizing an aqueous silver nitrate solution with the high-pressure wet-type jet mill (a), and that for a raw silver nitrate solution (b). 
ど高波数側へピークがシフトすることが知られている ${ }^{19)}$.この 両スペクトルより, $400 \mathrm{~cm}^{-1}$ 付近の吸収ピークが確認されないこ とから, 硝酸銀水溶液のみを湿式ジェットミル処理しても, 銀ナ ノ粒子は析出されないことを確認した.

Fig. 2 に，湿式ジェットミルの吐出圧を $100 \mathrm{MPa}$ に設定し，処 理回数を $5,10,20$ 回とし作製した試料のXRD パターンを示す. 比較として, 湿式ジェットミル未処理の試料の XRD パターンも 示す.すべての試料の XRD パターンにおいて，セルロースI型 結晶（JCPDS; 00-056-1718）に由来するピーク $\left(2 \theta=14.9^{\circ}, 16.4^{\circ}\right.$, $\left.22.7^{\circ}, 34.5^{\circ}\right)$ が確認された ${ }^{20)}$. CNF と硝酸銀水溶液の混合賏濁液 を湿式ジェットミル処理することにより, 銀結晶 (JSPDS: 00-0040783）に由来する回折ピーク $\left(2 \theta=38.1^{\circ}, 44.2^{\circ}\right)$ が確認され，処 理回数の増加に伴い, 銀由来の回折ピーク強度が増加しているこ とを明らかとした. このことより, 処理回数の増加に伴い析出し た銀粒子の量が増加していることが推察される.湿式ジェットミ ル処理を行っていない試料には, 銀の回折ピークは確認されなか ったため, 湿式ジェットミル処理により銀イオンが還元され, 銀 粒子が析出したと思われる.

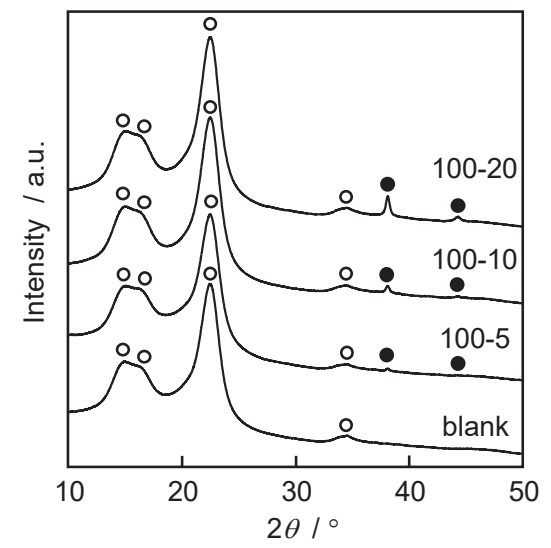

Fig. 2 XRD patterns of samples prepared with a high pressure wet jet mill at 100 MPa pressure. $\bigcirc$ : Cellulose, $O$ : Silver

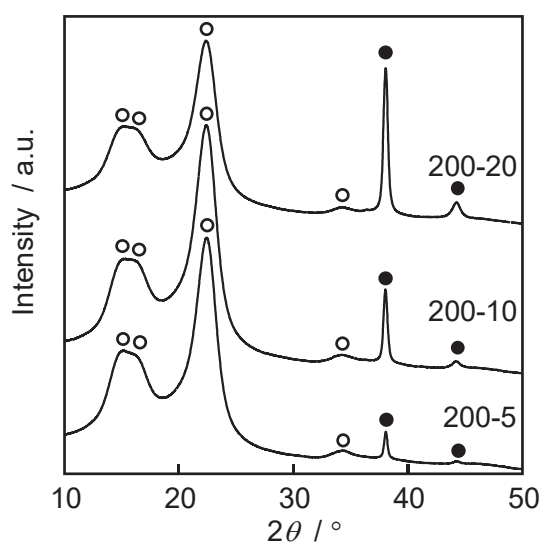

Fig. 3 XRD patterns of samples prepared with a high pressure wet jet mill at 200 MPa pressure. $\bigcirc$ : Cellulose, $\mathrm{O}$ : Silver

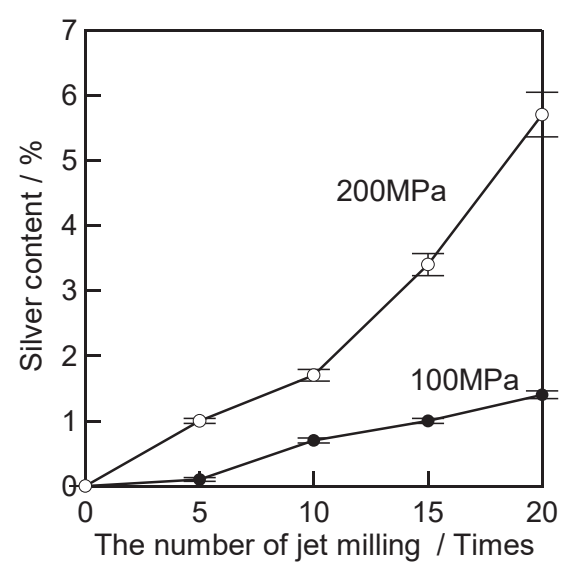

Fig. 4 Relationship between silver content and the number of jet milling.

湿式ジェットミルの吐出圧を $200 \mathrm{MPa}$ に設定し，処理回数を 5, 10, 20 回とし作製した試料の XRD パターンを Fig. 3 に示寸. $100 \mathrm{MPa}$ 処理と同様に銀由来の回折ピークが確認され, CNF と 銀の $2 つ の$ 結晶構造を有していることが確認された. また, 処理 回数の増加に伴い, 銀由来の回折ピーク強度は増加し, 同じ処理 回数の $100 \mathrm{MPa}$ 処理の試料と比較して, より強度が増加してい ることが確認された. したがって, 吐出圧の高い方がより多くの 銀粒子が析出していると推察される.

Fig. 4 に，各試料中の固形分量に対する銀含有量を示寸. 吐出 圧に関わらず, 処理回数の増加に伴い, 銀の含有量が増加してい ることが明らかとなった. 吐出圧 $100 \mathrm{MPa}$ での処理の場合, 処 理回数の増加に伴い, 緩やかに銀含有量が増加し, 20 回処理を 行った試料の銀含有量は $1.4 \%$ であった. 吐出圧 $200 \mathrm{MPa}$ での処 理の場合, 処理回数の増加に伴い, 急激な銀含有量の増加が確認 され，20回処理を行った試料の銀含有量は，5.7\%であった. い ずれの処理回数でも, 高い吐出圧で作製した試料の方が銀含有量 が多いことがわかった。

Fig. 5 に各処理条件で作製した試料の FE-SEM 観察像を示寸. すべての試料で䋊維幅が約 $20 \mathrm{~nm}$ のファイバーが凝集せず，網 目構造を形成していることが観察された.この網目構造を形成し ているのが CNF であり，その表面には $10 \mathrm{~nm}$ 以下のサイズの粒 子が点在している様子が確認された. XRD パターンの結果より, このナノ粒子が銀であり, 銀ナノ粒子は, 互いに凝集せず, CNF 上に均一に分散していることが明らかとなった. 吐出圧に関わら ず，5回処理した試料では，粒子数は少量であるが，処理回数の 増加に伴い, 粒子数は増加している様子が観察できた. このこと は, XRD パターンの銀由来のピーク強度や銀含有量の結果とも 一致する. 本手法により作製した試料は，CNF 上に銀ナノ粒子 を均一に分散担持させた複合体であることが明らかとなった。

Fig. 6 に各処理条件で作製した試料の TEM 観察像を示す。す べての試料において, 粒子サイズは $5 \mathrm{~nm}$ 以下であり, 粒度が揃 っていることが確認できた. また, 粒子同士の凝集は確認できず, 銀ナノ粒子は, 分散している状態であることを確認した. 観察用 試料の作製時, 溶媒を蒸発させる必要がある. その際, 仮に, CNF に固定化されていない銀粒子が存在している場合, 銀粒子の凝集 


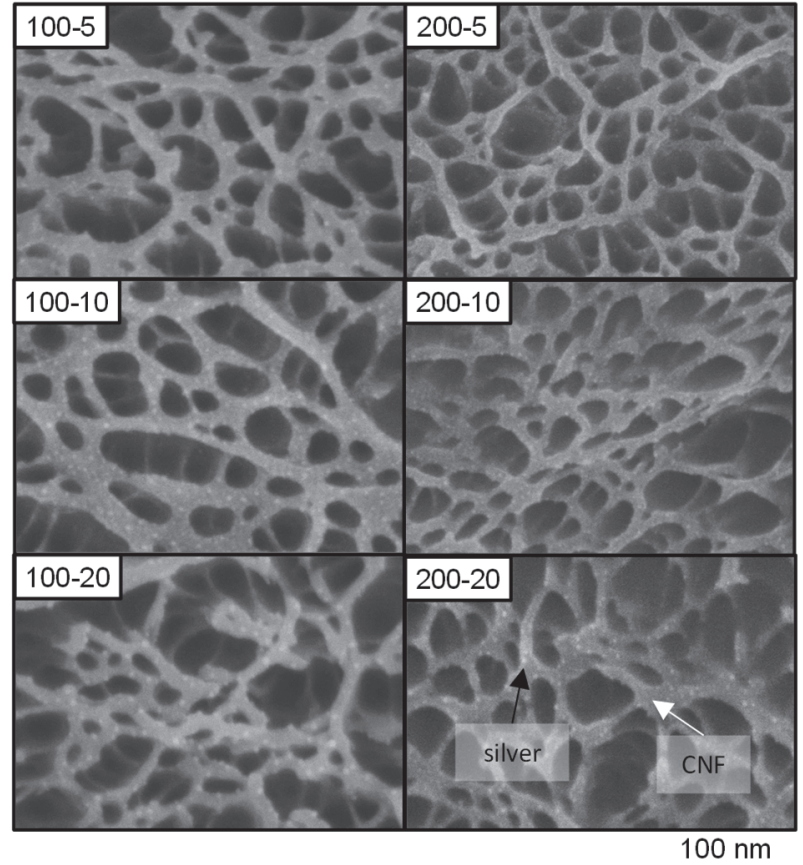

Fig. 5 FE-SEM micrographs of the samples prepared with a high pressure wet jet mill. White arrow: CNF, Black arrow: Silver nanoparticle

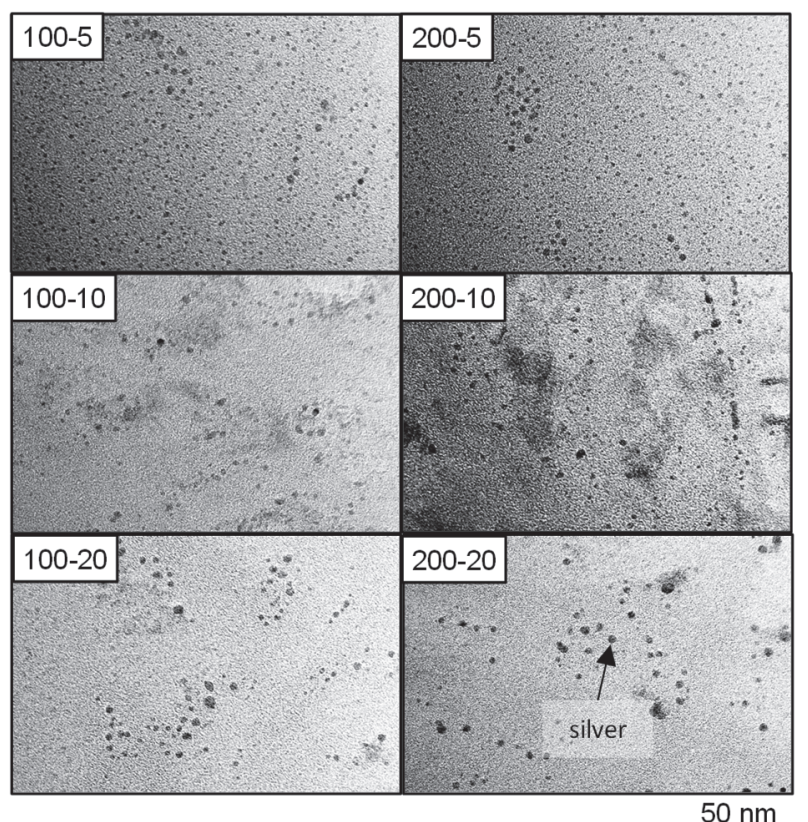

Fig. 6 TEM micrographs of the samples prepared with a high pressure wet jet mill. Black arrow: Silver nanoparticle

塊などが数多く観察されるはずであるが, 今回のTEM観察では, 凝集塊が確認できなかったことより，銀粒子はCNF 上に固定化 されていることが推察される.FE-SEM像で観察されたCNFは, TEM の観察像では，明膫な観察はできなかった．水素，炭素， 酸素の軽元素から構成されている CNF は, TEMによる観察を行 う際にコントラストを向上させる目的で, リンタングステン酸や 䣷酸ウラン等の重金属を含有寸る試薬で電子染色を行う必要が

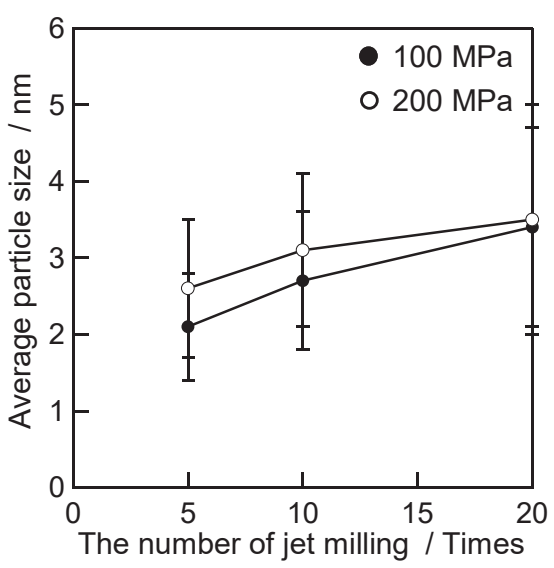

Fig. 7 Average particle sizes for the samples prepared with the high-pressure wettype jet mill at $100 \mathrm{MPa}, 200 \mathrm{MPa}$, respectively.

あるが 21,22), 電子染色を行った場合, 試料の周囲に重金属が残存 し，正確な銀粒子の計測が困難になる. 本報では，正確な粒子サ イズの測長のため電子染色を行わず観察した.

Fig. 7 には, Fig. 6 に示した TEM 観察像より, 粒子を測長して 算出した各試料中の銀ナノ粒子の平均粒子サイズを示す. 吐出圧 が 100MPa で，5 回，10 回，20 回処理した試料の平均粒子サイ

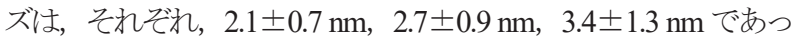
た. 処理回数の増加に伴い, 平均粒子サイズは若干増大している が, すべての処理回数で, 非常に微小で粒子サイズが揃った銀ナ ノ粒子であることが確認された. 吐出圧が $200 \mathrm{MPa}$ で, 5 回, 10

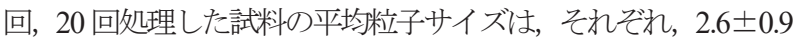
$\mathrm{nm}, 3.1 \pm 1.0 \mathrm{~nm}, 3.5 \pm 1.5 \mathrm{~nm}$ であり, $100 \mathrm{MPa}$ 処理の試料と同 様, 非常に微小で粒子サイズが揃った銀ナノ粒子が析出している ことが明らかとなった. また, 処理圧力は粒子サイズにほとんど 影響を及ぼさないことを確認した。

\section{4 湿式ジェットミル処理による銀粒子の析出機構}

湿式ジェットミル処理により銀粒子が形成する機構に関して, 考察を行う。本実験で用いた湿式ジェットミル装置は, 直径 100 $\mu \mathrm{m}$ のノズルから原料流体を衝突チャンバーにある窒化ケイ素 製のボールへ高圧で吐出させることにより, 原料流体に, せん断 力や衝突力を与える装置である. ベルヌーイの定理を用い23), 本 装置の衝突チャンバー内の流体速度を算出した結果, 吐出圧 100 $\mathrm{MPa}$ で $447 \mathrm{~m} / \mathrm{s}$, 吐出圧 $200 \mathrm{MPa}$ で $632 \mathrm{~m} / \mathrm{s}$ であり, 非常に速い 流速であることがわかる.このように, 高圧で吐出された原料流 体には, 圧力差により短時間に泡の発生と消减が起きる物理現象 であるキャビテーションが生じていると推測される.このような, キャビテーションを利用した銀粒子の生成について報告がある.

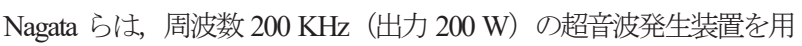
い, 10 分以上キャビテーションを生じさせて, 銀粒子を析出させて いる ${ }^{24)}$. 本報では, Fig. 1 に示すように，硝酸銀水溶液を湿式ジ エットミルにより, 吐出圧 $200 \mathrm{MPa}$ で，20 回処理を行ったが, 銀粒子の析出は確認出来なかった. このことより, 本実験のキャ ビテーションだけでは, 銀イオンの還元反忘は進行しないことが 
分かる。

Fig. 8 に湿式ジェットミルの衝突チャンバーの後に流通する冷 却管の影響を検討するため, 冷却管の有無の条件で，吐出圧 100 MPa および $200 \mathrm{MPa}$ で処理した純水の温度変化を示寸。泠却管 がない場合, 吐出圧 $100 \mathrm{MPa}$ では 1 回の処理のみで, 液温が 24.8 ${ }^{\circ} \mathrm{C}$ から $48.1{ }^{\circ} \mathrm{C}$ まで急激に上昇していることがわかった。 その後 も処理回数の増加に伴い, 液温は上昇し, 20 回処理した時, 74.3 ${ }^{\circ} \mathrm{C}$ であった．また，吐出圧 $200 \mathrm{MPa}$ では 1 回の処理のみで，液 温が $67.9^{\circ} \mathrm{C}$ にまで急激に上昇し, 2 回目の処理で， $80.8^{\circ} \mathrm{C}$ まで 上昇した. 3 回目の処理で飽和温度となり, それ以降, 約 $84^{\circ} \mathrm{C}$ を維持していた。 このように, 冷却管がない場合, 液温が急激に 上昇することが明らかとなった。

一方，冷却管を使用し $10^{\circ} \mathrm{C}$ に設定している場合，吐出圧や処 理回数に関わらず, 液温は約 $14^{\circ} \mathrm{C}$ を維持していることがわかっ た.これらのことより, 試料作製時の湿式ジェットミルの衝突チ ヤンバー内では,キャビテーションと衝突時の運動エネルギーが 熱エネルギーに変換されることにより，溶液は，一瞬，約 $50^{\circ} \mathrm{C}$ (吐出圧 $100 \mathrm{MPa}$ 時) または約 $70^{\circ} \mathrm{C}$ (吐出圧 $200 \mathrm{MPa}$ 時) まで 加熱されている. その際, 僅かではあるが, 還元能を有寸るCNF が隣接していることにより, 銀イオンが銀に還元されると考えら れる 25. また，CNF を湿式ジェットミル処理することにより， CNF が，更に粉砕され，CNF の分子鎖末端に由来寸る還元性官 能基がファイバー表面に多く露出することにより, 更に銀イオン の還元が促進されたことも要因の一部であると思われる ${ }^{13}$. CNF の表面をミクロフィブリル化させ, より多くの還元性官能基を生 成させる目的で, 湿式ジェットミル処理を行っている. フィブリ ル化とは, 繊維構造の表面が毛羽立ってくる現象である. その結 果, セルロースの分子鎖末端が多く生成し, 還元性官能基が増加 していると考えられる. 既報では, $\mathrm{CNF}$ と硝酸銀水溶液を混合 し， $60^{\circ} \mathrm{C}$ で 2 時間還流寸ることにより，銀粒子が析出すること を確認している. その還流法により析出した銀粒子は, 粒子サイ ズが大きく, 粒度分布幅も広かった ${ }^{13}$. しかし, 湿式ジェットミ ルでは, 衝突チャンバー内で, 一瞬の夕液温が上昇し, 粒子は析 出寸るが, その後, 直ちに冷却管により冷却されるため, 粒成長

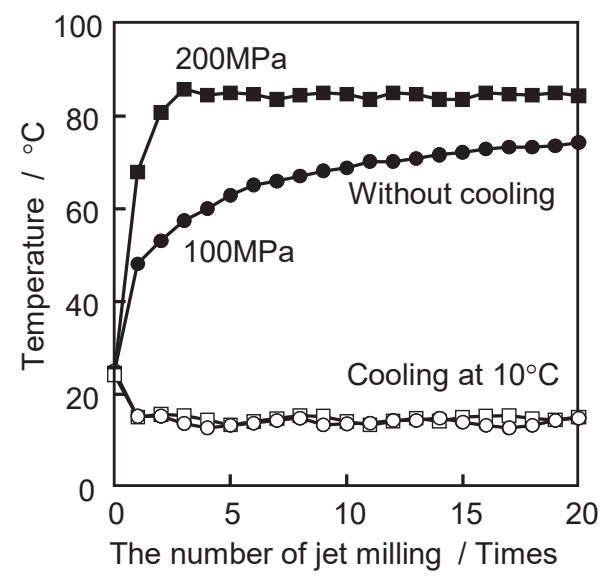

Fig. 8 Relationship between water temperature and the number of jet milling.

: $100 \mathrm{MPa}, \bigcirc: 100 \mathrm{MPa}$ with cooling at $10^{\circ} \mathrm{C}, \square: 200 \mathrm{MPa}, \square: 200 \mathrm{MPa}$ with cooling at $10^{\circ} \mathrm{C}$
は抑制され，分散夜中で均一なサイズの銀ナノ粒子が $\mathrm{CNF}$ 上に 固定化されたと考えられる.この粒子の析出機構は, マイクロ リアクターを用いた粒子の析出機構と非常に類似していると推 察される. Singhらは, マイクロリアクターを利用し, 粒子サ イズの均一な銀ナノ粒子の作製を報告している29. マイクロリ アクターを利用するマイクロ化学プロセスでは, 流体チャンネ ルの温度と反応時間を精密に制御することにより，粒子の核形 成と粒成長を制御し，粒子サイズの均一なナノ粒子を作製する ことが可能である．また，吐出圧を高くすることは，発熱温度 の上昇に繋がり，処理回数を多くすることは，銀粒子の核形成 量の増加と粒成長に繋がる. 一回の湿式ジェットミル処理で生 じる核形成および粒成長の工程時間は等しいため, 処理回数の 増加に伴い，固定化される銀粒子のサイズは若干増加した。ま た，吐出圧の上昇に伴い，液温が上昇するため，銀の析出反応 が促進され，銀含有量は増加し，さらに処理回数の増加に伴い 銀含有量も増加したと推察される. 銀イオンの還元を担う過剩 の還元剂や熱量が極度に少ない条件であるため, 粒子サイズを 制御できたと推察される．また，CNF上の分子鎖末端の還元能 を利用しているため, 瞬時にCNF 上に銀が析出される.このた め, PVP のような保護材を用いることなく，粒子同士の凝集を 防止できたと推察される.

\section{5 結 言}

$\mathrm{CNF}$ と硝酸銀水溶液の混合矁濁液を湿式ジェットミルの処理 条件を変更し処理することにより, 銀ナノ粒子を析出させ CNF 上に固定化した．銀粒子は，平均粒子サイズが $2.1 〜 3.5 \mathrm{~nm}$ であ り，非常に均一な粒度であることが分かった．また，銀粒子は凝 集することなく，CNF 上に固定化されていた．湿式ジェットミ 儿処理回数の増加に伴い, 銀粒子のサイズは大きくなり, 処理回 数と吐出圧を増加させることにより, 銀含有量は増加した. 湿式 ジェットミル処理により，混合䀣濁液が装置内部で瞬間的に加 熱・冷却されることにより, 均一かつ微小な粒子サイズの銀ナノ 粒子が析出し, CNF 上に固定化されたと推察される.

\section{参 考 文 献}

1) I. Sondi and B. Salopek-Sondi, "Silver nanoparticles as antimicrobial agent: a case study on E. coli as a model for Gram-negative bacteria”, Journal of Colloid and Interface Science, Vol.275, No.1, pp.177-182 (2004).

2) Y. Li, Y. Wu and B. S. Ong, "Facile synthesis of silver nanoparticles useful for fabrication of high-conductivity elements for printed electronics", Journal of the American Chemical Society Vol.127, No.10, pp.3266-3268 (2005).

3) D. D. Evanoff, R. L. White and G. Chumanov, "Measuring the distance dependence of the local electromagnetic field from silver nanoparticles", The Journal of Physical Chemistry B, Vol.108, No.5, pp.1221-1231 (2004).

4) A. Murugadoss and A. Chattopadhyay, "A 'green' chitosansilver nanoparticle composite as a heterogeneous as well as micro-heterogeneous catalyst”, Nanotechnology, Vo.19, No.1, 
pp.015603 (2008)

5) A. Henglein and M. Giersig, "Formation of colloidal silver nanoparticles: capping action of citrate", The Journal of Physical Chemistry B, Vol.103, No.44, pp.9533-9539 (1999).

6) R. Jin, Y. W. Cao, C.A. Mirkin, K. L. Kelly, G. C. Schatz and J. G. Zheng, "Photoinduced conversion of silver nanospheres to nanoprisms", Science, Vol.294, No.5548, pp.1901-1903 (2001).

7) P. Y. Lim, R. S. Liu, P. L. She, C. F. Hung and H. C. Shih, "Synthesis of Ag nanospheres particles in ethylene glycol by electrochemical-assisted polyol process", Chemical Physics Letters, Vol.420, No.4-6, pp.304-308 (2006).

8) S. I. Dolgaev, A. V. Simakin, V. V. Voronov, G. A. Shafeev and F. Bozon-Verduraz, "Nanoparticles produced by laser ablation of solids in liquid environment", Applied Surface Science, Vol.186, No.1-4, pp.546-551 (2002).

9) M. Husein, E. Rodil and J. H. Vera, "Formation of silver bromide precipitate of nanoparticles in a single microemulsion utilizing the surfactant counterion", Journal of Colloid and Interface Science, Vol.273, No.2, pp.426-434 (2004).

10) A. Sarkar, S. Kapoor and T. Mukherjee, "Synthesis and characterisation of silver nanoparticles in viscous solvents and its transfer into non-polar solvents", Research on Chemical Intermediates, Vol. 36, pp.411-421 (2010).

11) T. Nishino, K. Takano and K. Nakamae, "Elastic modulus of the crystalline regions of cellulose polymorphs", Journal of Polymer Science Part B Polymer Physics, Vol.33, No.11, pp.1647-1651 (1995).

12) H. Yano, J. Sugiyama, A. N. Nakagaito, M. Nogi, T. Matsuura, M. Hikita and K. Handa, "Optically transparent composites reinforced with networks of bacterial nanofibers", Advanced Materials, Vol.17, No.2, pp.153-155 (2005).

13) E. Fujii and M. Furutani, "Fabrication of silver nanoparticles using high-pressure wet-type jet mill', Materials Transactions, Vol.59, No.9, pp.1483-1486 (2018).

14) R. J. Chimentão, I. Kirm, F. Medina, X. Rodríguez, Y. Cesteros, P. Salagre and J. E. Sueiras, "Different morphologies of silver nanoparticles as catalysts for the selective oxidation of styrene in the gas phase", Chemical Communications, Vol.7, pp.846847 (2004).

15) M. Maillard, S. Giorgio and M.-P. Pileni, "Silver nanodisks", Advanced Materials, Vol.14, No.15, pp.1084-1086 (2002).

16) E. Hao and G. C. Schatz, "Electromagnetic fields around silver nanoparticles and dimers", The Journal of Chemical physics, Vol.120, No.1, pp.357-366 (2004).

17) A. D. Westland and R. R. Langford, "Determination of nitrate in fresh water", Analytical Chemistry, Vol.28, No.12, pp.19961998 (1956).

18) V. Tomišić and V. Simeon, "Ion association in aqueous solution of strong electolytes: a UV-Vis spectrometric and factoranalytical study", Physical Chemistry Chemical Physics, Vol.1, pp.299-302 (1999).

19) P. Billaud, J.-R. Huntzinger, E. Cottancin, J. Lermé, M. Pellarin, L. Arnaud, M. Broyer, N. Del Fatti and F. Vallée, "Optical extinction spectroscopy of single silver nanoparticles", The European Physical Journal D, Vol.43, pp.271-274 (2007).

20) Q. Li and S. Renneckar, "Supramolecular structure characterization of molecularly thin cellulose I nanoparticles", Biomacromolecules, Vol.12, No.3, pp. 650-659 (2011).

21) Y. Su, C. Burger, B. S. Hsiao and B. Chu, "Characterization of TEMPO-oxidized cellulose nanofibers in aqueous suspension by small-angle X-ray scattering", Journal of Applied Crystallography, Vol.47, pp.788-798 (2014).

22) T. Saito, S. Kimura, Y. Nishiyama and A. Isogai, "Cellulose nanofibers prepared by TEMPO-mediated oxidation of native cellulose", Biomacromolecules, Vol.8, No.8, pp.2485-2491 (2007).

23) G. A. Lindsay, "Pressure energy and Bernoulli's principle", American Journal of Physics, Vol.20, pp.86-88 (1952).

24) Y. Nagata, Y. Watananabe, S. Fujita, T. Dohmaru and S. Taniguchi, "Formation of colloidal silver in water by ultrasonic irradiation", Journal of the Chemical Society, Chemical Communications, Vol.21, pp.1620-1622 (1992).

25) E. J. Parks and R. L. Herbert, "Thermal analysis of ion exchange reaction products of wood pulps with calcium and aluminum cations", Tappi Journal, Vol.55, No.10, pp.15101514 (1972).

26) A. Singh, M. Shirolkar, N. P. Lalla, C. K. Malek and S. K. Kulkarni, "Room temperature, water-based, microreactor synthesis of gold and silver nanoparticles", International Journal of Nanotechnology, Vol.6, No.5, pp.541-551 (2009). 